\title{
Economic Water Reallocation in the Zayande Rood Basin (Iran) Among Different Uses via Designed Software
}

\author{
Leila ALLAHDADIAN Department of Administrative Sciences \\ and Economics, University of Isfahan, \\ M.A graduated student \\ Email: leilaallahdadian@yahoo.com \\ Rahman KHOSHAKHLAGH Department of Administrative Sciences \\ and Economics, University of Isfahan. \\ Full professor \\ Email: Rahmankh44@yahoo.com
}

ABSTRACT A 15-meter decrease in underground water level and several-years of drought which have afflicted the Gavkhooni swamp, signify inappropriate allocation of the available water.

The rapid growth in population as well as increase in water demand due to municipalities, expansion of industrial activities, farming has put a lot of pressure on existing water in the Zayande Rood basin.This paper claims that the centralized method of water allocation directed under the supervision of a public institution has lost its credibility and does not harmonize with the institutional setting of the water market. With the use of a non-centralized method, such an institutional setting can be more efficiently utilized. But before implementing changes, with a laboratory-type experience we can examine probable changes. Therefore in this article a computerized water allocation system for the purpose of using the water market has been devised and it is shown that efficiency increases. Such allocation has been implemented for the river basin of Zayande Rood in (Isfahan) Iran.

KEY WORDS Water, Laboratory experiment, Competitive market, Reallocation, Efficiency

JEL CODES Q25, C90, D41, Q29, D61.

DOI: 10.6007/IJAREMS/v2-i6/428 URL: http://dx.doi.org/10.6007/IJAREMS/v2-i6/428

\section{Introduction}

Many of the large, complex water systems throughout the world depend upon a centralized authority both to solve the fundamental coordination problems and to dictate solutions to 
allocation issues. In our world of rapid technological and environmental change, these centrally managed systems tend to react too slowly to allow society to adapt efficiently. One of the problems with proposals for substantial institutional change in water systems are that modification and irreversibility make the process slow, cautious and costly to society. Experimental economics can play in evaluating proposed institutional changes to help facilitate a more rapid and smooth adoption of changes in the water system. The essential idea is to combine the information and incentive advantages of decentralized ownership rights or responsibilities with the coordination advantages of central processing.

Water experts observe that the present problems of Zayande Rood are due to the extreme use of water from the river, violation of existing water-rights, drought, overuse of water facilities, traditional irrigation as well as rapid increase in the population. The foundation of too many industrial plants resulting from bad decision making on behalf of the government, in this region puts high pressure of the river's water supply.

Drought has damaged the agriculture sector severely in this region, because when drought occurs, the residential and industry sectors are given priority.

On the other hand, the upstream section of the river after Zayande Rood dam does not experience any water limitation in times of drought; therefore the full impact of drought pressures is imposed on the downstream section of the river. With better supervision of the upstream section and the use of appropriate strategies for proportionate share of the water supply at times of drought between upstream and downstream sectors, there will result a higher efficiency in water allocation.

Water transfer from other regions has reached its limit. Therefore, the only option is using the existing water supply more efficiently.

The most important point that must be taken into consideration, is the property rights of owners in the related region and eschewing political concerns.

There are a lot of legal complexities in determining water-rights due to the existence of a previous decree named "Tomar Sheikhbahaee", the significance of inter-basin water transfer and the construction of different dams as well as government regulation imposed on appropriated the existing water in the river .Solving these complexities and determining waterrights must precede water allocation. In this paper, it is assumed that all existing water supplies are allocated by an over-ruling decree. Laboratory experiments are a formal, replicable, and relatively inexpensive means of analyzing different market mechanisms. An experimental approach certainly has great promise for testing institutional variants to inform the public policy debate, and to familiarize decision-makers and principals with market mechanisms. 
The proposed allocation process of the water market was simulated in the laboratory. The users of the water are the industrial, agricultural, residential and environmental sectors; the allocation is conducted by our designed software.

This paper tries to persuade the authorities to allocate the reliable water supply in different uses efficiently.

\section{Background}

Previous studies regarding the Zayande Rood basin have concentrated on estimating the demand function in the basin for the residential, industrial and agricultural sectors. Maximum willingness to pay on the various sectors has been obtained through estimated demand functions.

Abtahi(1994) has estimated five demand functions of the residential water in different districts of the Zayande Rood basin. The total demand function of residential water has been obtained through the horizontal summation of five demand functions.

Maximum willingness to pay for the purpose of environment preservation has been obtained by Kave (1997). Maximum willingness to pay for the environment sector or maximum willingness to preserve water quality is considered for boating to ensure that the maximum willingness to pay is adequate for the preservation of the environment of Gavkhooni swamp.70 million cubic meters is the minimum quantity for the preservation of the environment of the Gavkhooni swamp (Table1).

We have referred to the estimate offered by (Rezaee, 2007), for the maximum willingness to pay for the agricultural sector.

Both maximum willingness to pay and water needed per hectare have been provided in this research (Tables 2-6).

Rajabi(2007) has calculated the final price for the industry sector. The final price of water in the industry sector is 4500 Rials per cubic meter. This price is considered as the maximum willingness to pay for the user in the industry sector .The required water for this sector is 150 million cubic meters.

Nouralizadeh (1997) has presented the supply function, Therefore, we can estimate the quantity of water supply for various prices.

Morphy and et all (2000) tried to reallocate the existing water supplies of California using laboratory experiments which we have used in our research, despite the limitations in our supply and demand domain. 
In both the Morphy et all (2000) and our research the aim has been the determining of success due to institutional changes in the water market.

\section{Method and material}

Experimental Economics is a branch of Economics which uses controlled experiments to evaluate theories and behavioral assumptions, as well as to test policies and their implementation. In contrast to Econometrics, which uses existing field data and often makes strong statistical assumptions, Experimental Economics aims at generating "tailor-made" data to help answer specific questions without requiring auxiliary assumptions?

Experiments typically take place in computer laboratories. The controlled environment allows experimenters to measure the effect of variables of interest while isolating that of others. Experiments thus allow clear causal inference to be made in a way which is often impossible outside the laboratory. In experiments participants face abstract scenarios that do not reveal information about the goals of the study and receive payments for the decisions they make. The latter comes in contrast to the experimental methodology used in disciplines such as Psychology, where individuals are usually asked hypothetical questions and are not given monetary incentives to reveal their true preferences.

Easter, et al. 1998, provide evidence indicating that the development of markets can improve water allocation by permitting the compensated, voluntary transfer of water to its highest-valued use.However, the allocation of private property rights can be successful only if there is an efficient mechanism to allocate and trade the rights. Although the advantages of water markets are well prescribed, economic theory says little about how different market institutions can affect allocations. Experimental research clearly indicates that the rules governing trading play a vital role in determining the market outcomes and the realized gains from trade (Smith 1982; Kagel 1995).

In the water market of Zayande Rood basin, we can divide suppliers into two categories:

1- suppliers of surface water

2- suppliers of underground water (deep and semi-deep wells)

The current conditions of the water market are as the follows: there exists an authoritarian water supplier and users i.e. individuals who own water rights but can not sell water independently.

But this experiment has two categories of suppliers for surface water. One is the Regional Water Company and the other the sub-regions which despite having the right to use water do 
not use it; rather they are inclined to sell their water- right to other sub-regions. In these markets, when the sub-region has a lower maximum willingness to pay than the equilibrium price, they sell their water right to the others for profit. Both purchaser and seller profit through this transaction.

Underground waters have been used only in their sub-regions and are not transferable. Therefore, purchasing and selling underground water is not carried out in the market and does not play an active role in this market.

This paper aims to determine the main users in the region and the markets which are formed through them. If all users and their consumption levels were included in the experiment, it would become too complicated. Therefore Bon and Saman, Lenjanat, Qomshe, Najafabad, Isfahan Borkhar and Gavkooni only are selected as the main users.

The Zayande Rood basin has 4 main purchasers for the residential, one for the industrial, one for the environmental and 5 for the agricultural uses. (Table7)

In our laboratory experiment, Bon and Saman, Lenjanat, Qomshe, Najafabad, Isfahan Borkhar was selected as the main agricultural users. (Table 8) Isfahan Borkhar, Najafabad, Lenjanat, Qomshe were selected as the main residential users (Table 9).

The main user of surface water for industry is Lenjanat, because it includes two industrials units, FooladMobarake and ZoobAhan. (Table 10).

The main user for the environmental sector is the Gavkhooni swamp. The Gavkhooni sub-region is the main user for the preservation of the environment and which needs at least 70 million cubic meters.

The key components of this market are:

1- $\quad 80 \%$ of the water is used in the agriculture sector

2- It supplies both surface and underground water

3- We consider surface water as the only interchangeable commodity in the market.

4- It involves 3 activities, including purchasing, selling and transferring in the market

5- We presuppose the existence of a permanent surface water resource called Zayande Rood

6- It considers 4 sectors including the agricultural, industrial, residential and environmental in the market

7- We consider the transfer cost for transferring of surface water 


\section{Calculation}

Since the current estimated demand and supply functions were supposed to be correctly concluded, if the reallocation could improve efficiency, it could be concluded that reallocation would be practical in the real world and lead to higher efficiency. If efficient reallocation did not take place, the tester would have to experiment with the demand and supply functions obtained in the laboratory and then examine efficiency.

According to the demand and supply functions for the industrial, agricultural, residential and environmental sectors, it is possible to simulate the water market of Zayande Rood in a laboratory. Based on the conditions of the laboratory and available data, including maximum willingness to pay and maximum willingness to supply or sell supply and demand quantities with different prices and the current conditions of allocation in the basin, equilibrium prices are established without any interference of the (public) Regional Water Company.

\subsection{The performed experiment via designed software}

For the purpose of the reallocation of water in the Zayande Rood basin to different users, we designed our own software to implement water allocation in this experiment.

The agents were divided into two groups: agents who represented water right holders in our experiment and the supervisor of water allocation in the role of the Regional Water Company in the real world.

The agents were selected from among undergraduate students of Isfahan University. The considered time for this experiment was a maximum of 2 hours (of which the participants were informed beforehand).Furthermore, other students worked in this experiment as test assistants. In the first stage of the experiment which was carried out as an exercise, the assistants had to help agents to operate, but they had no effect on the agents' decisions. The tester explained about the experiment, how it was carried out, and presented the related software in 10 minutes. Then, some papers were distributed among the agents to inform them. Then, agents were given time to ask questions and the tester answered according to the planned framework.

The agents' earning is 10 dollars for participation and a maximum of 100 dollars based on performance. In the experiment, the agent with maximum earning has 100 dollars and the others have lower earnings.

The experiment was carried out as described below.

The supervisor starts the pre-purchasing stage. The supervisor announces the price to the agents and they consider the announced price and compare it with their willingness to pay, if 
the price is higher than willingness to pay, they decline to buy any quantity and push the delete button. In the case that prices are lower than willingness to pay, agents choose their quantities and the request is submitted to the system, then it is aggregated for all the agents. The supervisor, having access to the Supply Function and the amount of water the water- right holders are willing to sell in this price range determines whether the equilibrium price is obtained or allocation with further change in price should be persuaded. When the price reaches 300 Rials, the supplier and the right holders are ready to sell water and the equilibrium price is reached (Table 11).

In the purchase stage, the supplier announces that 1235 million cubic meters water will be sold at the price of 300 Rials.

In the purchasing stage $1235 \mathrm{~mm}^{3}$ of water which is offered in reality by the Regional Water Company is sold to the purchasers. The rest of purchasers who were unable to buy in this stage will purchase in the inter-regional transaction stage from the seller sub-regions.

There are two ways to get the responses of purchasers: random and quota.

Since in the purchasing stage there is no need for the agents to pay money for water transfer, they are inclined to buy as much as possible in this stage. Therefore, there may occur a rush for purchase. To avoid such a rush two methods were considered to promote smooth interaction.

In the first stage of our experiment, the random method was applied and the purchasers were selected by software; the selected ones were presented on the right side of the monitor and asked to purchase only once. After each agent purchases, the supervisor selects the next agent. This follows until the end of the 1235 million cubic meters of water. It is possible that the last agent be unable to purchase the total requested water from the supervisor; in this case, the software informs the agent of the purchase quantity. Then transfers the reminder to purchase form for the next stage. In the current stage, the software is able to divide the purchase quantity into two parts: purchased and non-purchased.

When the supplier cannot sell water to the demanders, the inter-regional transactions start. The time anticipated for this stage is about 10 minutes the remaining time is announced by a timer seen on the monitor.

In the interregional transactions, agents have to pay the transfer cost for purchasing, so the positions of the sub-regions are shown on the monitor (Table 12).

By the inclusion of this map in the software, the information process is clear for the agents. 
Agents who have decided to buy from outside of their sub-regions pay the transfer cost to the representative of the related region providing services of transfer. All agents are isolated in this stage and in the other stages and must not speak to each other, so their connections are via chat. After the time is finished for trade-off, the inter-regional transactions become inactive and there is no permission for further transaction. The software informs the agents how much they purchased, who purchased from whom, how much transfer cost was paid and how much profit was gotten in each stage and finally how much profit was earned totally.

This information is also sent to the supervisor to determine the efficiency of each transaction.

In the quota method, some proportions of all supplied water are given to the agents. (Table 13)

In this method, in contrast to the "random" method in which the agent may obtain all needed quantities in the purchasing stage and not enter the interregional transactions stage, all agents participate in the latter stage since they have obtained only a portion of their needed quantity in the purchasing stage.

Total Demand quantity at equilibrium price $=1472.1$

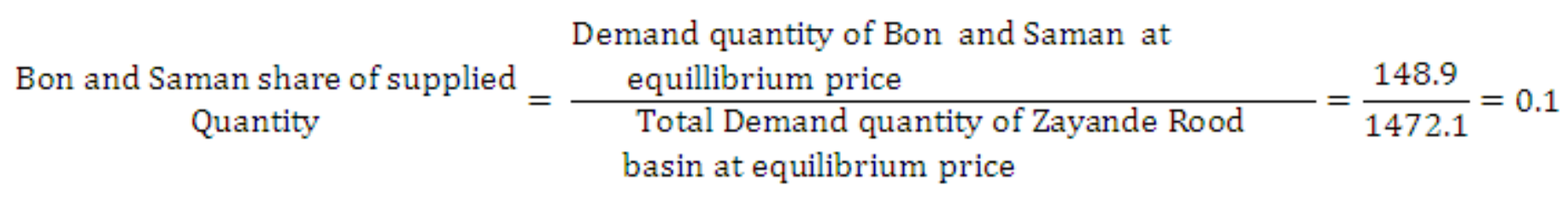

Bon and Saman Share quantity $=$ total supplied quantity $\times$ Bon and Saman share $=1235.2 \times 0.1$ $=123.5$

In the quota method, the pre-purchasing stage is completely equal to what is done in the random stage. After reaching the equilibrium price and the sale is announced by the supervisor, the agents start to purchase considering the share allocated to them.

Then, a GO button which appears and disappears in various places of each monitor made by the software is used for making arrangements for purchasing in the laboratory. Each agent who presses this button faster, can purchase from the supplier and begin purchasing in the interregional transaction, this follows to the end.

Therefore, this is a good time to transact with nearer sub-regions and pay less transfer costs and earn more profit. 
The difference of the inter-regional transactions in this method and the random method is that all agents start to do the transaction simultaneously in the random method, but in the quota method, each agent who finishes his or her quota purchase sooner, can enter the interregional transactions. Speed is a main factor of success for the agent to gain profit in this method.

The time for doing these inter-regional transactions is 10 minutes and after this time, the inter-regional transactions become inactive and finally, the information is sent to each supervisor and related agents.

\section{Result and discussion}

The current centralized method of water allocation in the region in which all that should be carried out in a free market is done by a public institution has been unacceptable for many years now and is not in harmony with the rate of progress in today's modern world. An enhancement towards a competitive state of allocation should, nevertheless be under the supervision of the institution which currently manages allocation. In the Zayande Rood region, water is obtained from current water-right holders who are active in the agriculture sector without any payment of money to them and is given to the industry and residential sectors. This causes severe damage to the agriculture sector without considering the injustice and inequality thus imposed. This article aims at establishing the premise that the current regional problem will not be solved by violating the rights of water-right holders in the agriculture sector; on the contrary all their lawful rights should be observed and a permit for water sale should be given to them and a new system of water allocation should be established. This development will result in the elimination of the monopoly on water allocation of a monolithic authority (the Regional Water Company) and the advancement toward a semicompetitive market (thus increasing efficiency from the researchers' point of view) on the one hand, and the obliteration of injustice in the water market on the other. The findings of this research are expressible in the form of answering the following hypothesis.

Hypothesis: using semi-competitive markets of water under supervision will lead to increase in allocation efficiency.

Two benchmarks including efficiency and surplus distribution are applied for representing the results of the experiment. Efficiency and surplus rely on measures of the gains from trade to evaluate market performance. In the efficiency benchmark, the earned profit by the agents is compared with theoretical quantities gotten from demand and supply functions. 
Efficiency shows the markets' ability in obtaining the potential gain of transaction.

$$
\mathrm{EFF}=\frac{\pi_{\mathrm{Buy}}^{*}+\pi_{\mathrm{gell}}^{\mathrm{*}}}{\pi_{\mathrm{Buy}}^{\mathrm{ce}}+\pi_{\mathrm{gell}}^{\mathrm{ce}}} \in[0,1]
$$

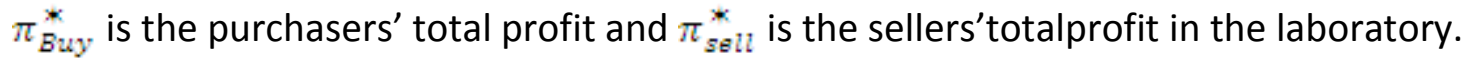

$\pi_{B u y}^{c e}$ is the purchasers' total profit and $\pi_{S e n}^{C e}$ is the sellers' total profit in the competitive market.

If the assimilated market is practically closer to the competitive market, efficiency will be closer to one quantitatively. The equilibrium quantities shown by stars are obtained from suggestions and requests. We can, as a tester, consider the real supply and demand functions, and use them in order to calculate the competitive price and profit. The equilibrium quantities are shown by ce since competitive equilibrium, which are used as the measure for comparison. The competitive equilibrium results in an allocation that maximizes the total possible surplus, thus, a perfectly competitive market will be 100 percent efficient. Similarly, a measure of the individual performance of a particular subject is the ratio of the actual experimental earnings to the profits that would have been earned in the perfectly competitive equilibrium. Because individual subjects can earn super-competitive profits, it is possible that this ratio can exceed 100 percent for some (but not all) participants; however, the market efficiency, which includes all subjects' earnings, can never exceed 100 percent.

Surplus distribution shows the purchasers' and sellers' profit share relative to the total profit obtained in the exercise. The more the share of the purchasers and the less the share of the sellers, the more competitive the market will be.

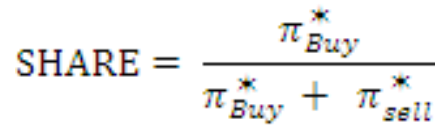

$$
\begin{aligned}
& \text { SHARE }=\frac{\pi_{\text {Sell }}^{*}}{\pi_{\text {Buy }}^{*}+\pi_{\text {sen }}^{\star *}}
\end{aligned}
$$

The purchasers' and sellers' profit is calculated as follows:

Purchasers' profit= good value - price

Sellers' profit $=$ price - good cost 
The agriculture sector's profit from purchasing water from the other sub-regions= good value (water price + transfer cost)

The residential and industry sectors' profit from purchasing water from the Regional Water Company $=$ good value - (price + filtration cost)

The residential and industry sectors' profit from purchasing water from the other supplier subregions $=$ good value $-($ price + filtration cost + transfer cost

The results of research from the experiment are as follows:

$$
\begin{aligned}
& \text { EFF }_{\text {random }}=\frac{\pi_{\text {Duy }}^{\mathrm{s}}+\pi_{\mathrm{gell}}^{\mathrm{s}}}{\pi_{\mathrm{Buy}}^{\mathrm{ce}}+\pi_{\mathrm{gell}}^{\mathrm{ce}}}=\frac{210060.54}{255670.24}=0.82 \\
& E F F_{\text {qouta }}=\frac{212174.98}{255670.24}=0.829
\end{aligned}
$$

purchasers and sellers share in the random method

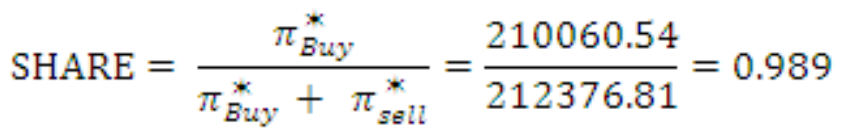

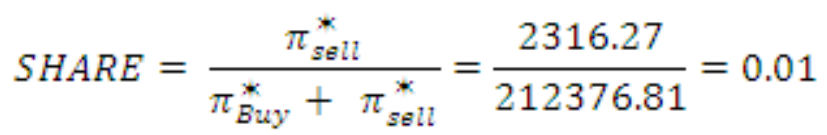

purchasers' and sellers'share in the quota method

$$
\begin{aligned}
& \text { SHARE }=\frac{208947.54}{212174.98}=0.984 \\
& \text { SHARE }=\frac{3227.44}{212174.98}=0.015
\end{aligned}
$$

The high proportion of purchasers and low proportion of sellers in earning profit shows the correctness of the experiment. In a competitive market, the purchaser has a high proportion and sellers get profit zero from the transactions.

In both the random method and the quota method the share of the Regional Water Company which has the role of supervisor in the experiment, is zero, and the sub-region water sellers 
make a profit from the sale of water. A positive amount of profit for some sellers of water seen in the experiment is due to the semi-competitive status of the market.

What do the results from these laboratory micro economies tell us about the design of market institutions in the "real world"? The applicability of experimental results to the understanding of similar non-laboratory situations is referred to as parallelism (Smith 1980).

Clearly, the experiments reported in this paper are a stylized representation of Zayande rud region's water network. However, the laboratory experiments allow us to learn about the water market institution in a simple environment that we can control. This permits us to build of body of evidence identifying the strengths and weaknesses of an institution, and provides an opportunity to develop modifications at a relatively low cost before implementation in the field. Thus, laboratory experiments can provide valuable insights to reduce the uncertainty inherently associated with the implementation of new institutions. (Plott, 1987).

Laboratory Economics is unknown in Iran and those who are acquainted with the concept still do not have faith in it and do not, therefore, use it as a substitute method but rather as a complementary one. This study used Laboratory Economics as the research method for the first time in Iran and it has been the aim to make the least possible amount of mistake. The ultimate aim was to devise software which could allocate water in the region intelligently. This aim was very closely approximated; the only remaining step is for the software to take all possible conditions in the random method into consideration and show the best possible condition in which the sub-regions can obtain maximum profit. Since this is a big feat, the researchers have not so far been able to reach such an aim and suggest it for future studies.

\section{References:}

1. Abtahi, A., 1994. Estimating of demand for residential water, M.A Thesis, Isfahan, Isfahan University.

2. Easter, K.W., M.W. Rosegrant and A. Dinar, eds. (1998), Markets for Water: Potential and Performance. Norwell, MA: Kluwer Academic Publishers.

3. Hassan Shahi, M., 1994. Economical analyses of physical transfer of water for Arsanjan city, M.A Thesis, Isfahan, Isfahan University.

4. Hatano,T.,Okuda,T., 1997.Water Resource Allocation in the yellow river Basin, applying a CGE model, Gradate school of environmental studies, Nagoya university, Japan

5. Kagel, J.H. (1995), 'Auctions: A Survey of Experimental Research', The Handbook of Experimental Economics. Princeton, NJ: Princeton University Press, pp. 501-585. 
6. Kaveh, R.,1997. Selection Of suitable Quality for Water, Case of study: Zayande Rood basin, M.A Thesis, Isfahan, Isfahan University.

7. Murphy, J. J., and et all.,2000. The Design of Smart Water Market Institutions Using Laboratory Experiments, University of Massachusetts.

8. Plott, C.R. (1987), 'Dimensions of Parallelism: Some Policy Applications of Experimental Methods', Laboratory Experimentation in Economics: Six Points ofView. New York: Cambridge University Press, pp. 193-219.

9. Nooralizade, L.,1998. Analyses of economic supply function in Zayande Rood basin, Isfahan, Khorasgan University.

10. Rezaee, GH., 2007. The Estimation Of Agricultural Water Demand Function In Zayande Rood Basin, M.A Thesis, Isfahan, Isfahan University.

11. Shahraki, J.,1995. Optimization Water Transfer of Hirmand River In Agricultural Sector, M.A Thesis, Isfahan, Isfahan University.

12. Smith, V.L. (1980), 'Relevance of Laboratory Experiments to Testing Resource Allocation Theory', Evaluation of Econometric Models. NewYork: Academic Press.

13. Smith, V.L. (1982), 'Microeconomic Systems as an Experimental Science', American Economic Review, 72, 923-955.

= Tables :

- Table:Maximum willingness to pay for maintaining of quality of water (Rial)

\begin{tabular}{||c|c|}
\hline \multicolumn{2}{|c|}{ Maximum willingness to pay (Rial) } \\
\hline \begin{tabular}{|} 
maintaining of quality of water for \\
boating
\end{tabular} & 14640 \\
\hline $\begin{array}{r}\text { maintaining of quality of water for } \\
\text { fishing }\end{array}$ & 11500 \\
\hline $\begin{array}{l}\text { maintaining of quality of water for } \\
\text { swimming }\end{array}$ & 10100 \\
\hline
\end{tabular}

Resource: kaveh (1997) 
- Maximum willingness to pay for the agriculture section in Zayande Rood region Table 2: Isfahan Borkhar

\begin{tabular}{|c|c|c|c|}
\hline Crop & $\begin{array}{l}\text { Economic value of one } \\
\text { cubic meter } \\
\text { (Rial) }\end{array}$ & $\begin{array}{l}\text { Delivery of water for one } \\
\text { hectare } \\
\left(M^{3}\right)\end{array}$ & $\begin{array}{l}\text { Hectares of } \\
\text { under } \\
\text { cultivation }\end{array}$ \\
\hline Potato & 1467 & 12564 & 850 \\
\hline Wheat & 535 & 11845 & 41500 \\
\hline Beet & 435 & 22676 & 468 \\
\hline Barley & 43 & 10068 & 7021 \\
\hline Cotton & 168 & 18791 & 3815 \\
\hline sunflower & 152 & 15138 & 250 \\
\hline
\end{tabular}

- Resource : Research finding and rezaei (2007)

- Table 3: Qomshe

\begin{tabular}{|c|c|c|c|}
\hline Crop & $\begin{array}{c}\text { Economic value of one } \\
\text { cubic meter } \\
\text { (Rial) }\end{array}$ & $\begin{array}{c}\text { Delivery of water for one } \\
\text { hectare } \\
\left(M^{3}\right)\end{array}$ & $\begin{array}{c}\text { Hectares of } \\
\text { under } \\
\text { cultivation }\end{array}$ \\
\hline Potato & 2660 & 12906 & 25 \\
\hline Wheat & 530 & 10360 & 7800 \\
\hline Beet & 446 & 8806 & 4100 \\
\hline
\end{tabular}




\begin{tabular}{|c|c|c|c|}
\hline sunflower & 288 & 15138 & 380 \\
\hline beet & 276 & 22676 & 50 \\
\hline
\end{tabular}

- Resource : Research finding and rezaei (2007)

- Table 4: Bon and Saman

\begin{tabular}{|c||c|c|c|}
\hline Crop & $\begin{array}{c}\text { Economic value of one cubic } \\
\text { meter } \\
\text { (Rial) }\end{array}$ & $\begin{array}{c}\text { Delivery of water for } \\
\text { one hectare } \\
\left(M^{3}\right)\end{array}$ & $\begin{array}{c}\text { Hectares of } \\
\text { under } \\
\text { cultivation }\end{array}$ \\
\hline \hline Potato & 2532 & 12906 & 2100 \\
\hline Beet & 377 & 22676 & 5000 \\
\hline Wheat & 310 & 10360 & 950 \\
\hline Barley & 302 & 8806 & \\
\hline
\end{tabular}

- Resource : Research finding and Rezaei (2007)

- Table 5: Lenjanat

\begin{tabular}{|c|c|c|c|}
\hline Crop & $\begin{array}{c}\text { Economic value of one } \\
\text { cubic meter } \\
\text { (Rial) }\end{array}$ & $\begin{array}{c}\text { Delivery of water for one } \\
\text { hectare } \\
\left(M^{3}\right)\end{array}$ & $\begin{array}{c}\text { Hectares of } \\
\text { under } \\
\text { cultivation }\end{array}$ \\
\hline Potato & 1212 & 12180 & 80 \\
\hline Barley & 230 & 8413 & 949 \\
\hline Wheat & 208 & 9898 & 940 \\
\hline
\end{tabular}

- Resource : Research finding and Rezaei (2007) 
- Table 6: Najafabad

\begin{tabular}{|c|c|c|c|}
\hline Crop & $\begin{array}{c}\text { Economic value of one cubic } \\
\text { meter } \\
\text { (Rial) }\end{array}$ & $\begin{array}{c}\text { Delivery of water for } \\
\text { one hectare } \\
\left(M^{3}\right)\end{array}$ & $\begin{array}{c}\text { Hectares of } \\
\text { under } \\
\text { cultivation }\end{array}$ \\
\hline Beet & 404 & 22676 & 0 \\
\hline Wheat & 365 & 10360 & 2500 \\
\hline Barley & 234 & 8806 & 1030 \\
\hline
\end{tabular}

- Resource : Research finding and Rezaei (2007)

- Table 7: Main purchasers of water for agriculture section

\begin{tabular}{||l|l|l|l|l|l|l|}
\hline Surface water & IsfahanBorkhar & Najafabad & $\begin{array}{c}\text { Bon } \\
\text { and } \\
\text { saman }\end{array}$ & Lenjanat & Qomshe \\
\hline $\begin{array}{c}\text { Underground } \\
\text { water }\end{array}$ & IsfahanBorkhar & Najafabad & Karron & Lenjanat & Qomshe \\
\hline
\end{tabular}

- Resource: Regional Water Company and Research finding (2006)

- Table 8; Main purchasers of water for residential section

\begin{tabular}{|c|c|c|c|c|}
\hline Surface water & Isfahan borkhar & Najafabad & Lenjanat & Qomshe \\
\hline Underground water & Najafabad & Lenjanat & Qomshe & \\
\hline
\end{tabular}

- Resource: Regional Water Company (2006)

- Table9: Main purchasers of water for Industry section 


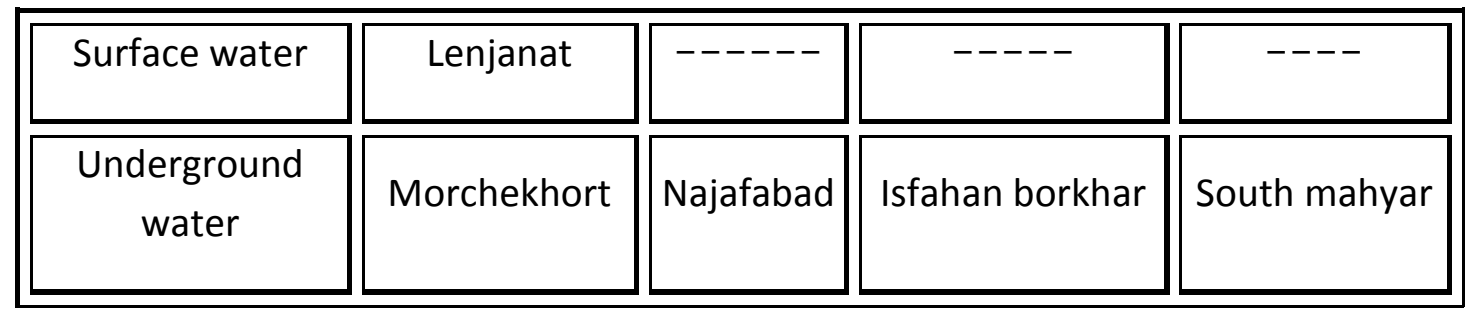

- Resource: Regional Water Company (2006)

- Table 10:Role of sub-regions in the experiment

\begin{tabular}{|c|c|c|}
\hline $\begin{array}{l}\text { Number of } \\
\text { sub-region }\end{array}$ & Sub-region & Role of Sub-region \\
\hline (1) & $\begin{array}{l}\text { Isfahan } \\
\text { borkhar }\end{array}$ & $\begin{array}{l}\text { Main purchaser for agriculture and residential } \\
\text { sections }\end{array}$ \\
\hline$(2)$ & Najafabad & $\begin{array}{l}\text { Main purchaser for agriculture and residential } \\
\text { sections }\end{array}$ \\
\hline (3) & Lenjanat & $\begin{array}{l}\text { Main purchaser for agriculture and residential } \\
\text { and industry sections }\end{array}$ \\
\hline (4) & Qomshe & $\begin{array}{l}\text { Main purchaser for agriculture and residential } \\
\text { sections }\end{array}$ \\
\hline (5) & Bon and saman & Main purchaser for agriculture section \\
\hline (6) & Gavkhouni & Main purchaser for protecting of environment \\
\hline (7) & $\begin{array}{l}\text { Regional water } \\
\text { company }\end{array}$ & Supplier of water \\
\hline
\end{tabular}

- Resource: research finding

- Table 11: market condition in the various prices in the laboratory 


\begin{tabular}{|c|c|c|c|c|c|}
\hline 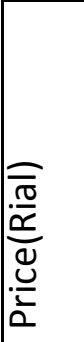 & $\begin{array}{c}\text { Quantity } \\
\text { of supply } \\
\text { of } \\
\text { Regional } \\
\text { Water } \\
\text { Company }\end{array}$ & $\begin{array}{l}\text { Supplied quantity by sub-region } \\
\qquad\left(M M^{3}\right)\end{array}$ & $\begin{array}{l}\text { Quantity } \\
\text { of } \\
\text { demand } \\
\left(M M^{3}\right)\end{array}$ & \multicolumn{2}{|c|}{$\begin{array}{c}\text { Demand or supply } \\
\text { surplus } \\
\left(M M^{3}\right)\end{array}$} \\
\hline 0 & $716 / 9$ & ------------ & $1736 / 65$ & $1019 / 75$ & $\begin{array}{l}\text { Demand } \\
\text { surplus }\end{array}$ \\
\hline 100 & $911 / 7$ & $0 / 67$ & $1735 / 98$ & $823 / 6$ & $\begin{array}{l}\text { Demand } \\
\text { surplus }\end{array}$ \\
\hline 150 & $1009 / 1$ & $0 / 67+29 / 6+0 / 68$ & 1705 & $664 / 98$ & $\begin{array}{l}\text { Demand } \\
\text { surplus }\end{array}$ \\
\hline 200 & $1090 / 9$ & $\begin{array}{c}0 / 67+0 / 68+29 / 6+3 / 8+71 / 7+ \\
0 / 45\end{array}$ & $1629 / 05$ & $431 / 25$ & $\begin{array}{l}\text { Demand } \\
\text { surplus }\end{array}$ \\
\hline 250 & 1158 & $\begin{array}{c}0 / 67+0 / 68+29 / 6+3 / 8+71 / 7+ \\
0 / 45+9 / 3+66 / 8+9\end{array}$ & $1543 / 95$ & $193 / 95$ & $\begin{array}{l}\text { Demand } \\
\text { surplus }\end{array}$ \\
\hline 300 & $1235 / 2$ & $\begin{array}{l}0 / 67+0 / 68+29 / 6+71 / 7+0 / 45+ \\
9 / 3+66 / 8+9+33 / 7+1 / 1+5 / 75+32\end{array}$ & $1471 / 4$ & $28 / 35$ & $\begin{array}{l}\text { Supply } \\
\text { surplus }\end{array}$ \\
\hline
\end{tabular}

- Resource: Research finding

- Table12: Transfer cost for purchaser sub-regions ( $M^{3}$ - Rial)

\begin{tabular}{||c|c|c|c|}
\hline \multirow{2}{*}{$\begin{array}{c}\text { Residential and } \\
\text { industry } \\
\text { sections }\end{array}$} & $\begin{array}{c}\text { Transfer } \\
\text { cost } \\
\text { regions }\end{array}$ & 500 & 2000 \\
\cline { 2 - 4 } & $\begin{array}{c}\text { Further sub- } \\
\text { regions } \\
\text { cost }\end{array}$ & $\begin{array}{c}\text { For all of } \\
\text { cases }\end{array}$ & 500 \\
\hline
\end{tabular}




\begin{tabular}{|c|c|c|c|}
\hline $\begin{array}{c}\text { Agriculture } \\
\text { section }\end{array}$ & $\begin{array}{c}\text { Tearer sub- } \\
\text { regions } \\
\text { cost }\end{array}$ & 200 \\
\cline { 2 - 3 } & $\begin{array}{c}\text { Further sub- } \\
\text { regions }\end{array}$ & 1200 \\
\hline
\end{tabular}

- Resource: Research finding

- Table 13: Share of sub-region

\begin{tabular}{|c|c|c|c|c|}
\hline $\begin{array}{c}\text { Name of sub- } \\
\text { region }\end{array}$ & $\begin{array}{l}\text { Quantity of } \\
\text { Demand of sub- } \\
\text { region in the } \\
\text { equilibrium price }\end{array}$ & $\begin{array}{c}\text { Total Quantity } \\
\text { of Demand in } \\
\text { the } \\
\text { equilibrium } \\
\text { price }\end{array}$ & $\begin{array}{l}\text { sub-region } \\
\text { share }\end{array}$ & $\begin{array}{c}\text { sub-region } \\
\text { sharequantity }\end{array}$ \\
\hline Bonand Saman & 148.9 & 1472.1 & 0.1 & 123.5 \\
\hline Najafabad & 85.6 & 1472.1 & 0.058 & 71.8 \\
\hline Qomshe & 124.1 & 1472.1 & 0.08 & 104.2 \\
\hline Lenjanat & 174.9 & 1472.1 & 0.12 & 148.2 \\
\hline Gavkhouni & 70 & 1472.1 & 0.47 & 580.5 \\
\hline $\begin{array}{l}\text { Isfahan } \\
\text { Borkhar }\end{array}$ & 868.6 & 1472.1 & 0.59 & 728.8 \\
\hline
\end{tabular}

- Resource: Research finding 